Original Paper http://ajol.info/index.php/ijbcs http://indexmedicus.afro.who.int

\title{
Morphological diversities and associated preference traits in Peanut (Arachis hypogaea L.) landraces from central and southern Benin
}

\author{
David MONTCHO ${ }^{*}$, Pascal GBÉNOU ${ }^{1}$, Antoine Abel MISSIHOUN ${ }^{2}$, \\ Fiacre ASSOGBA ${ }^{1}$, Djidjoho A.T. HODEHOU ${ }^{1}$, Christophe GANDONOU $^{3}$ and \\ Clément AGBANGLA ${ }^{2}$
}

\author{
${ }^{I}$ Ecole de Gestion et de Production Végétale et Semencière, Université Nationale d'Agriculture, \\ BP 43, Ketou, Benin. \\ ${ }^{2}$ Laboratoire de Génétique Moléculaire et d'Analyse des Génomes, Faculté des Sciences et Techniques (FAST), \\ Université d'Abomey-Calavi, 01 BP 526, Tri Postal, Cotonou, Benin. \\ ${ }^{3}$ Laboratoire de Physiologie Végétale et d'Etude des Stress Environnementaux, Faculté des Sciences et \\ Techniques (FAST), Université d'Abomey-Calavi, 01 BP 526, Tri Postal, Cotonou, Benin. \\ "Corresponding author; E-mail: montchodav@yahoo.fr
}

\begin{abstract}
Received: 04-05-2021
Accepted: 20-06-2021

Published: $30-06-2021$

ABSTRACT

Peanut (Arachis hypogaea L.) production in Benin is limited by several biotic and abiotic stresses. The objectives of this study were to document varietal trait preferences and peanut genetic diversity for breeding programs. A survey in the South and Center of Benin and an agro-morphological characterization was carried out. Results showed that farmers used five criteria, namely yield (seeds and pods), size of seeds, number of seeds per pod, oil content, and quality of the paste for selecting a variety. The clustering based on ten qualitative traits showed a variability structure in three groups based on the leaflets shape, plant habit, and branching pattern. The principal component analysis carried out on the quantitative traits indicated six groups of accessions. The group 3 of the latest analysis is composed of Azii alorga and Kamalo with interesting characteristics and showing a good criteria as seeds size $(\mathrm{SDL}=14.62 \pm 0.48 \mathrm{~mm})$, and pods size (average pod length and width respectively $\mathrm{PoL}=33.70 \pm 1.14 \mathrm{~mm}$, Pow $=14.87 \pm 0.29 \mathrm{~mm}$ ). The results should be prioritized for breeding programs to improve the good criteria found in other peanut varieties. It will be helpful for farmers in selecting performant varieties.
\end{abstract}

(c) 2021 International Formulae Group. All rights reserved.

Keywords: Arachis hypogaea, field survey, structure diversity, morphological variability, preference criteria.

\section{INTRODUCTION}

Peanut (Arachis hypogaea L., AABB, $2 \mathrm{n}=4 \mathrm{x}=40)$ is a self-pollinating legume widely produced in many regions of the world (Bertioli et al., 2019). Its global production was estimated at 48.7 million tons produced on 29.6 million hectares in 2019 (FAOSTAT, 2020). In West and Central Africa, peanut contributes to more than $50 \%$ of rural household income and is valued as a food due to its beneficial nutrients (Francisco et al., 2008; Desmae et al., 2019). Peanut grain 
provides quality vegetable oil, digestible protein $(26-30 \%)$, dietary fiber, minerals, and vitamins (Janila et al., 2013). Furthermore, the crop contributes to soil fertility through its nitroen-fixing capacity (Sanou et al., 2016).

In Benin, peanut is the second most cultivated legume after soybean (MAEP, 2018). The national yield estimated at 972.7 $\mathrm{Kg} / \mathrm{ha}$ is lower than the global yield (1647.4 $\mathrm{Kg} / \mathrm{ha}$ ) and the yield in neighboring countries such as Nigeria (1148.3 Kg/ha) and Cameroon (1123.6 Kg/ha) (FAOSTAT, 2020). The low yield is attributed to several major constraints including predator attacks, agricultural practices, and climatic factors (Hamasselbe et al., 2011; Loko et al., 2020). Availability of seed of quality respecting producers' preferences remains one of the challenges (Banla et al., 2018).

One possible way to increase peanut yield is to develop improved varieties through breeding programs. Last years in Africa, breeding programs have been initiated to enhance levels resistance to various biotic and abiotic stresses in legumes (Pandey al., 2016; Boukar et al., 2019). Paramount stage for plant breeding program is to constitute a broad genetic base of the germplasm through a core collection, and characterize the genetic diversity among the collection (Jiang et al., 2013). Genetic diversity is evaluated using agro-morphologic traits and molecular markers (Nkhoma et al., 2020). Although morphological traits are mostly influenced by environment (Dijkhuizen et al., 1996), morphological descriptors remain important for assessing genetic diversity, as they are the basis for varietal selection at the farm level (Dagnon et al., 2017). In addition, the awareness of information on the contribution of agronomic traits for diversity is becoming very useful in plant selection (Dwivedi et al., 2017). Research works about peanut in Benin are limited to pathogens studies and ethnobotanical surveys (Adjou et al., 2013;
Zinsou et al., 2018; Loko et al., 2020). The characterization of existing germplasm and the identification of grower's and processors variety preference criteria are poorly documented. In the current context of food insecurity, accentuated by climate change and the increasing demand of peanut on the international market, the study of diversity and the identification of traits of interest of peanut are essential.

\section{MATERIALS AND METHODS \\ Study areas}

Peanut growers and processors were surveyed in six (06) municipalities of southern and central Benin (Ketou, Cove, Djidja, Klouekanme, Dogbo and Ouesse) from June to July 2020 in order to analyze the peanut production system and grower's and processor's preferences criteria of varieties. The surveyed localities were previously identified for their relative importance in peanut production (Loko et al., 2020). All of them are located (Table 1; Figure 1) in a relatively subequatorial agro-ecological zone, with an average rainfall between 1100 to 1400 $\mathrm{mm} / \mathrm{year}$ and a temperature average oscillating between $21.2{ }^{\circ} \mathrm{C}$ and $32.5{ }^{\circ} \mathrm{C}$ (ASECNA, 2018). An experiment on agromorphological characterization was conducted in the municipality of Klouekanme (Figure 1). The soil of this municipality is ferralitic with a sandy-clay texture. Klouekanme has a hot, humid sub-equatorial climate with two rainy seasons and two dry seasons. Throughout the experiment, an average rainfall of $144.4 \mathrm{~mm}$ (September and October 2020) was recorded.

\section{Experimental design}

The design used was a randomized Fisher block with four replicates. Each replication of $4.2 \mathrm{~m}^{2}(6 \mathrm{~m} \times 0.70 \mathrm{~m})$ consists of 12 plots. A plot corresponds to an accession. The spacing between the replicates is $1.5 \mathrm{~m}$. Each plot consists of a single row of 
seedlings, with thirty (30) seedlings spaced 20 $\mathrm{cm}$ apart. The seedlings were sown in pure culture, at a rate of three seeds per hole. Two weedings were done respectively at 17 days after sowing (DAS) and 35 DAS.

\section{Data collection and analysis}

Fifteen (15) quantitative and 10 qualitative traits (Table 2) were used to characterize the landraces. The data were collected as recommended in the peanut descriptor (IBPGR, 1992). Two matrices were designed using the Excel spreadsheet. The first matrix concerns the varietal preferences criteria and the second is related to the agromorphological characterization. All the different statistical analyses were done with $\mathrm{R}$ software (Core Team R, 2018). The response frequencies of variety choosing criteria in different socio-professional groups (growers and processors) were calculated and presented in figures. Regarding the agro-morphological data, descriptive statistics (percentage, average, variance, etc.) were performed to describe the quantitative and qualitative variables. A hierarchical ascending classification was performed to group accessions according to their morphological similarity and principal component analysis to determine the quantitative traits that discriminate accessions. A hierarchical ascending classification with the UPGMA method (Unweighted Pair-Group Method using Arithmetic Averages) was then done with the quantitative traits that contribute the most to the PCA axes.

Table 1: Surveyed areas, ethnic groups and local names of accessions collected.

\begin{tabular}{lccc}
\hline Municipalities & Villages & Ethnic groups & Landraces \\
\hline Ketou & Ewe & Mahi & Wiwe olomoumeta \\
& Olouwachogo & Nagot & Azii Carder \\
& Adakplame & Mahi & Wiwe olomoumedji \\
& Golouhoue & Adja & Tondoun \\
Klouekanme & Mademe & Fon & Vedou \\
& Kpatakpodji & TS32-1 \\
Gjigbe & Fon Adja & Korgli \\
Dogbo & Adja & Wliwli \\
Ouesse & Zogba-trekou & Fon Mahi & Kamalo \\
& Gbanli-centre & Mahi Fon & Kpode - kpode \\
Cove & Naogon & Mahi & Azii alorga \\
& & Mahi & \\
\hline
\end{tabular}


Table 2: Variables collected.

\begin{tabular}{lc}
\hline Quantitative variables & Variable code \\
\hline Percentage seed germination $\%)$ & PSG \\
Days to maturity & DsM \\
Days to 50\% flowering & DsF \\
Days to 50\% emergence & DsE \\
Number of branches & NBr \\
Height of main stem (cm) & HMS \\
Plant spread (cm) & PLw \\
Leaflet length (mm) & LFL \\
Leaflet width (mm) & LFw \\
Number of seeds per pod & NSP \\
Pod length (mm) & PoL \\
Pod width (mm) & Pow \\
Seed length (mm) & SDL \\
Seed width (mm) & SDw \\
Weight of 100 seeds (g) & WgS \\
\hline Qualitative variables & PoC \\
\hline Type of inflorescence & Pariable code \\
\hline Stem pigmentation & Inf \\
\hline Stem surface & Pig \\
\hline Branching pattern & Stf \\
\hline Leaf colour & Lfc \\
\hline Leaf shape & Lfh \\
\hline Leaf surface & \\
\hline Growth habit & PrH \\
\hline Pod beak & \\
\hline Pod constriction & \\
\hline
\end{tabular}



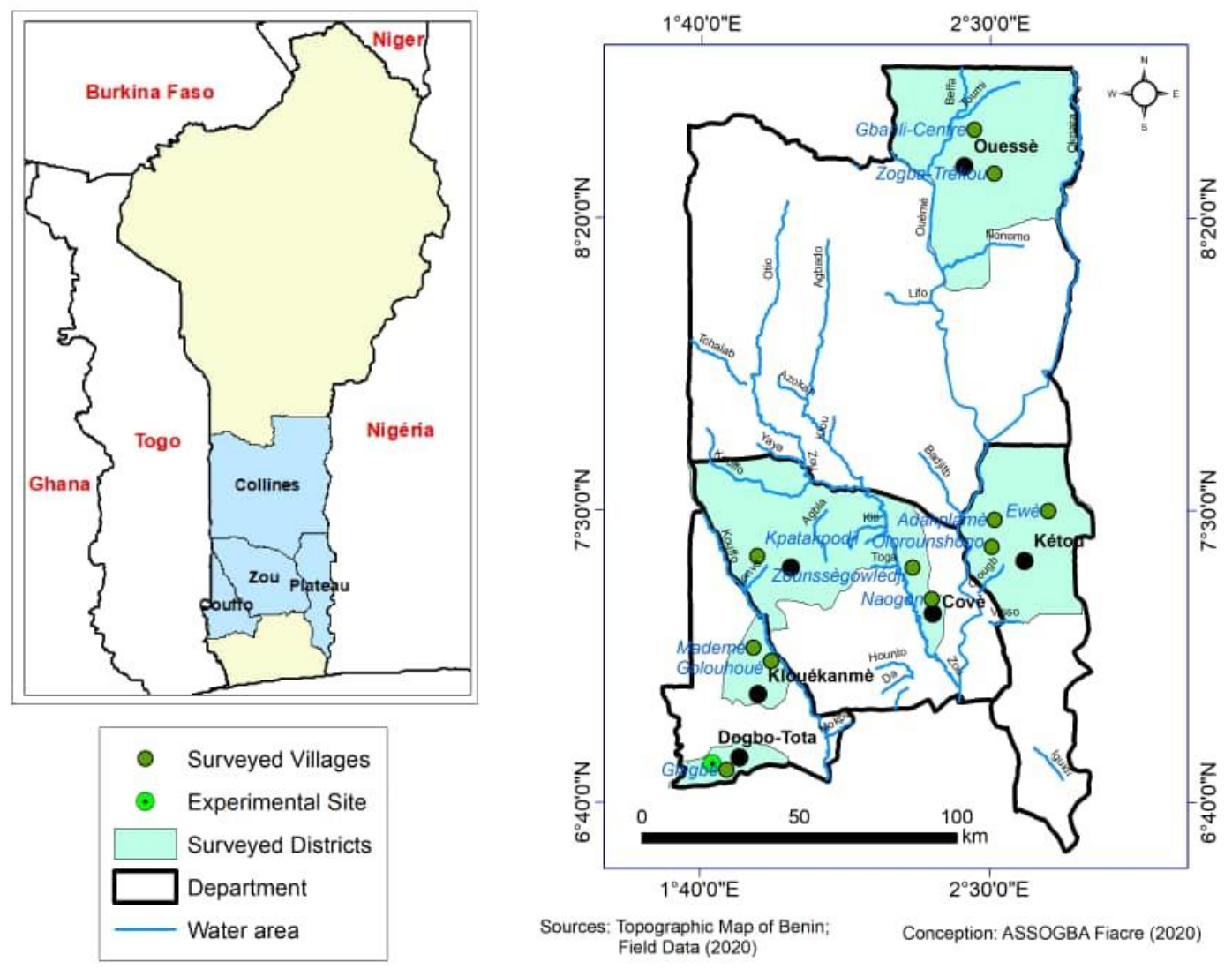

Figure 1: Map showing the study areas.

\section{RESULTS}

\section{Socio-demographic characteristics of the respondents}

On hundred and fourteen (114) people were surveyed, 74 men and 40 women. The average age of the respondents was $44 \pm 0.95$ years. More than half $(63.20 \%)$ of the respondents were illiterate. Approximately $27 \%$ of the respondents had received a basic education (primary school) and $9.60 \%$ have completed secondary school.

\section{Peanut production system}

Growers allocated total land areas ranging from 0.5 ha to 5 ha to peanut cultivation. Peanut processors and growers have an average experience of $18 \pm 1.56$ and $18 \pm 1.15$ years in the activity respectively. About fifteen percent (15.48\%) of the growers combine or alternate peanuts with other crops (maize, cassava, etc.). Eighty-four percent $(84.10 \%)$ of growers do not apply any fertilizer to peanuts, compared to $11.90 \%$ using NPKSB 14-18-6-1 for cotton or 15NPK 15-15 for other crops. Seeds from previous harvests $(89.29 \%$ of growers) and local market $(83.33 \%$ of growers) dominate the seed system. Only $1.2 \%$ of growers bought seeds from government services.

\section{Variety preference criteria of growers}

Figure 2 presents the traits preferred by growers in peanut varieties. The majority of growers $(89.28 \%)$ cited grain yield as the most important criteria for choosing varieties. Eighty-four percent $(84.52 \%)$ and $55.95 \%$ of growers preferred two-seed-per-pod varieties and small-seeded varieties. Pod yield and large-seeded varieties were cited by $53.57 \%$ of growers. About forty percent $(40.47 \%)$ of 
the growers prefer three seeded varieties per pod.

\section{Processors variety preference criteria}

Figure 3 presents the response rate of peanut processors on their varietal choice criteria. Oil content and the presence of two seeds per pod are traits preferred by $93.33 \%$ of processors. About fifty-seven percent (57.67\%) of them choose the large-seeded and good paste varieties of peanuts. Small seeded varieties and three seeded varieties per pod are preferred by $53.33 \%$ and $13.33 \%$ of processors respectively.

\section{Evaluation of agro-morphological variability of the collection Analysis of qualitative traits}

In the collection, $75 \%$ of the accessions presented an irregular branching pattern without flowers on the main stem and 25\% irregular branching pattern with flowers on the main stem. Sixteen percent $(16.67 \%)$ of the accessions have green leaflets, while $83.33 \%$ have pure green leaflets. Fifty percent $(50 \%)$ of the accessions studied had narrowelliptic terminal leaflets, $25 \%$ had broadelliptic terminal leaflets, $16.67 \%$ had oblongelliptic terminal leaflets, and $8.33 \%$ had lanceolate terminal leaflets. All accessions (100\%) have pilose on both sides of the leaves and white stems with pilose. Fifty percent $(50 \%)$ of accessions have an erect habit while $50 \%$ are creeping. All accessions (100\%) have simple inflorescences. Fifty percent $(50 \%)$ and thirty-three percent $(33.34 \%)$ of the accessions have moderate and prononced pods constriction, respectively. Seventy-five percent $(75 \%)$ of the collection had pods with light beaks, compared to $25 \%$ with pronounced beaks.

\section{Analysis of quantitative traits}

Results of analyses performed on quantitative traits show the highest germination rate in Awozi Olomon Meta and Wliwli accessions and the lowest germination rate in TS32-1 accession. The average higher elongation of plant was $28.2 \pm 1.04 \mathrm{~cm}$. The highest elongation $(33.13 \mathrm{~cm})$ was obtained in
Azii yaya accession while the lowest (21.88 $\mathrm{cm})$ was obtained in TS32-1 accession. The average plants height was $14.74 \pm 0.87 \mathrm{~cm}$. The accession Azii alorga had the highest height $(17.81 \mathrm{~cm})$, while the lowest $(9.06 \mathrm{~cm})$ was observed on TS32. The average leaf width was $23.52 \pm 0.52 \mathrm{~mm}$. Azii alorga showed the highest leaf width $(26.5 \mathrm{~mm})$ and Tondoun the lowest $(20.75 \mathrm{~mm})$. The maximum number of seeds (3) was obtained in the accessions Awozi Olomon Meta, Azii Carder, Tondoun, Kamalo, and TS32-1. The accessions Vedou, Korgli, Wliwli, KpodeKpode, Aziii yaya which contain two seeds per pod have a less interest of producers. The accession Azii alorga showed the highest $(26.5 \mathrm{~mm})$ leaflet width, while the lowest $(20.75 \mathrm{~mm})$ leaflet width was found in Tondoun. The highest leaflet length was obtained with the accession Azii alorga (58.25 $\mathrm{mm})$ and the lowest with Azii Carder (45.25 $\mathrm{mm})$ accession. The highest pod length was recorded on the Kamalo (34.54 $\mathrm{mm})$ accession, while the lowest $(23.31 \mathrm{~cm})$ was observed with Awozi Olomon Médji. Accessions Azii alorga and Kamalo showed the maximum $(14.88 \mathrm{~mm})$ pod width, while TS32-1 accession showed the minimum (11.77 mm). Regarding seed length, the highest seed length $(15.08 \mathrm{~mm})$ was obtained on Azii alorga accession while the lowest $(11.41 \mathrm{~mm})$ was observed on Awozi Olomon Médji accession. Concerning the seed width, Azii Carder showed the highest width (9.99 $\mathrm{mm})$ and Wliwli the lowest $(8.08 \mathrm{~mm})$. The highest weight of 100 seeds $(55 \mathrm{~g})$ was obtained with the Azii alorga accession, whereas the lowest (39.9 g) was for Wliwli.

Concerning the emergence time, the shortest time was observed with Wliwli accession ( 6 days) and the longest (10 days) in Korgli and Azii alorga. Similarly, the earliest (21 days) flowering plants were observed on Wliwli accession, while the lastest were observed in Azii alorga (31 days). Regarding the number of pods per plant, the average was $8.12 \pm 0.46$. As concerning the number of branches, Azii yaya accession showed the 
highest number (5.75) while TS32-1 showed the lowest number (4.2).

\section{Diversity structure based on qualitative traits}

The clustering based on the qualitative traits has grouped the 12 accessions into three (03) classes (Figure 4). Class C1 contained only Wliwli accession, which has the particularity of having lanceolate leaflets. Class C2 contained the accessions Awozi Olomon Meta, Azii Carder, Korgli, KpodeKpode, Awozi Olomon Medji, and Azii alorga, mainly characterized by a creeping habit. Class C3 grouped the accessions with an erect habit and those with dominantly irregular stem branching pattern and flowers on the stem. Class 3 contained the accessions Tondoun, Azii yaya, Kamalo, TS32-1 and Vedou.

\section{Diversity structure based on quantitative traits}

The principal component analysis (PCA) on data revealed that the two first axes explained $85.98 \%$ of the total variation. These two axes have been selected with the most contributing traits to perform the agglomerative hierarchical clustering.

The cluster based on the PCA data presents all accessions into 6 groups as shown in Figure 5. Group I, contains only TS32-1 accession, characterized by the average of the main stem $(\mathrm{HMS}=9.06 \pm 0.32 \mathrm{~cm})$ and the average rate of germination $(\mathrm{PSG}=5.5 \%$ ) that is lower than all other groups. In addition, a short spread (PLw $=21.86 \mathrm{~cm})$ of the accession TS32-1 has the lowest number of branches $(\mathrm{NBr}=4.18)$ and pods per plant (NSP $=4.63)$. Group II is composed of Awozi Olomon Medji and Tondoun accessions with flowering time ( $\mathrm{DsF}=27.75$ days) longer than the average time of all other groups. The accessions of group II produce small seeds $(\mathrm{SDL}=11.46 \mathrm{~mm})$. Azii alorga and Kamalo, enclosed by group III, showed interesting characteristics. In addition to producing the longest seeds $(\mathrm{SDL}=14.62 \mathrm{~mm})$ and leaflets $(\mathrm{LFL}=56.75 \mathrm{~mm})$, accessions have the largest pods (pods length and width respectively $\mathrm{PoL}=33.70 \mathrm{~mm}$, Pow $=14.87$ $\mathrm{mm}$ ) in the studied collection.

In Group IV (Figure 5), Azii Carder accession is characterized by large seeds $(\mathrm{SDw}=10 \mathrm{~mm})$, while group $\mathrm{V}$ contains the accessions Korgli and Awozi Olomon Meta with the shortest $(50 \%)$ emergence time (DsE $=6$ days). The accessions Wliwli, Azii yaya, Vedou and Kpode-Kpode, belonged to group VI which has the particularity of producing only two seeds per pod (NSP $=2$ ).

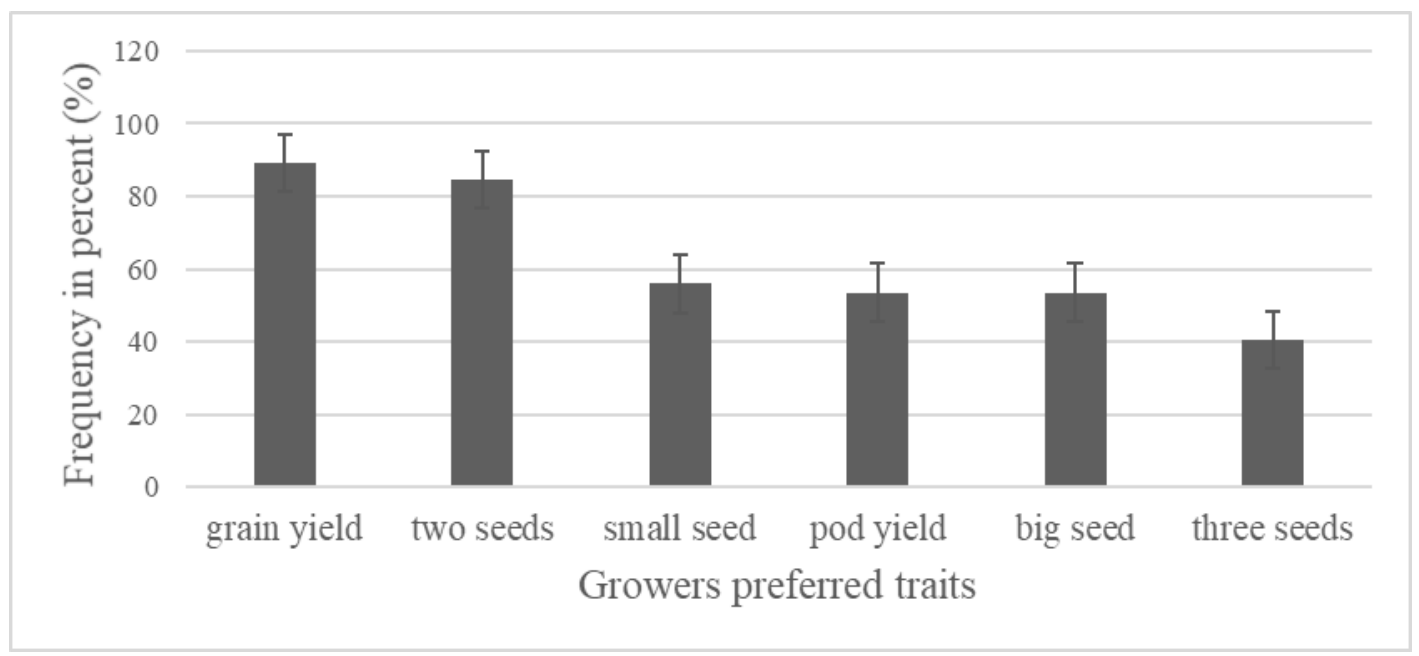

Figure 2: Peanut growers' preference criteria. 


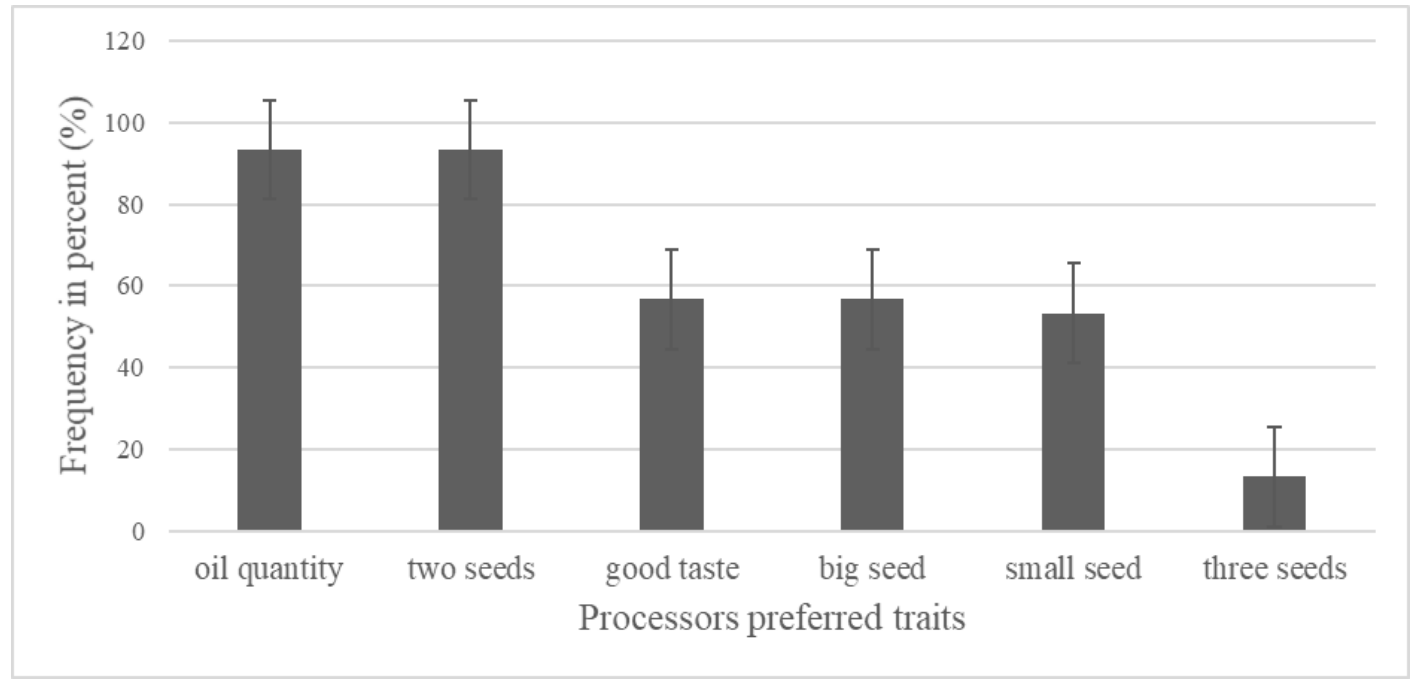

Figure 3: Peanut processors' preference criteria.

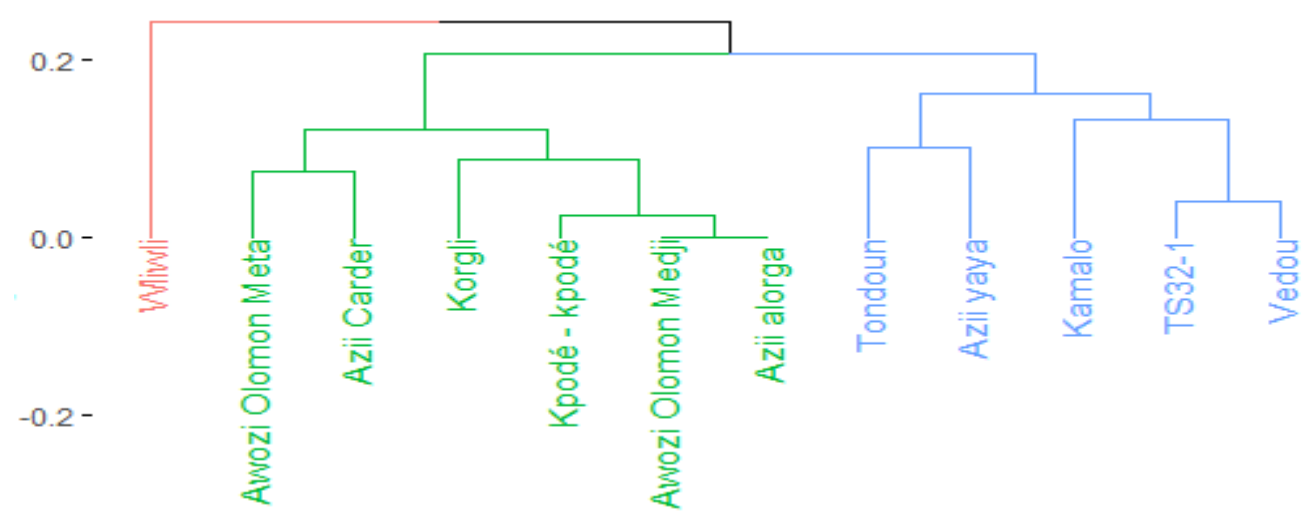

Figure 4: Peanut accessions classification based on qualitative traits.

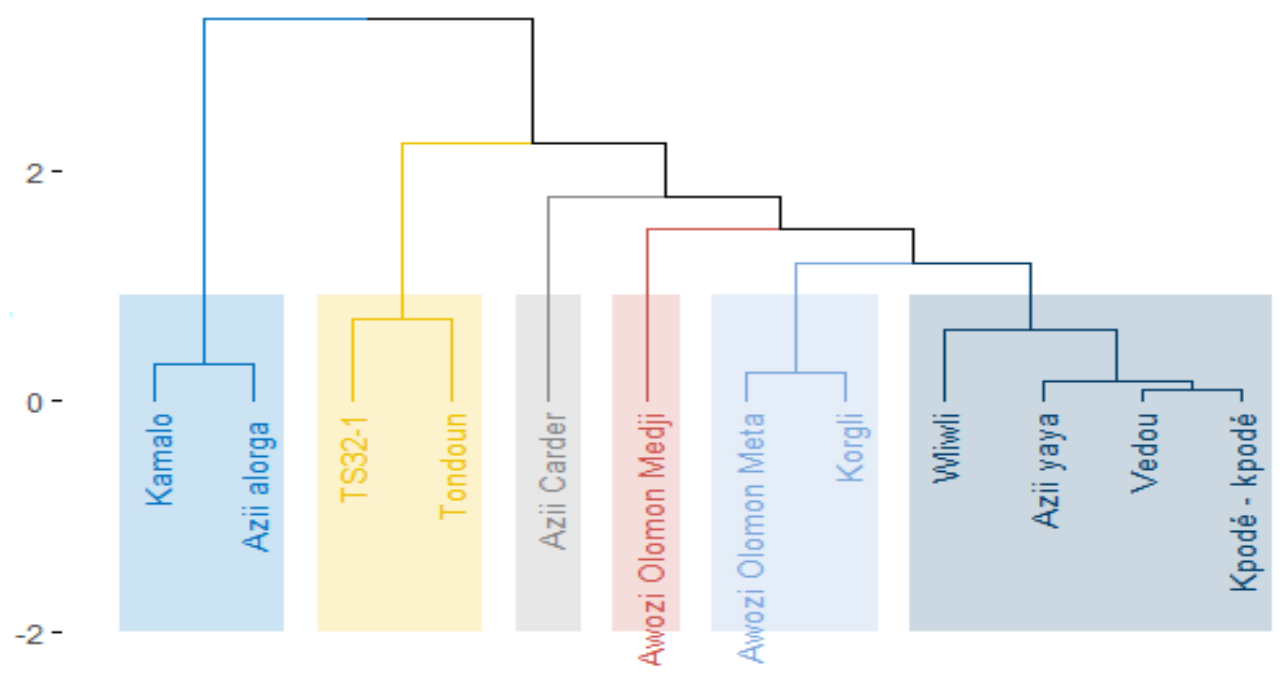

Figure 5: Peanut accessions classification based on quantitative traits. 


\section{DISCUSSION}

The stakeholder's aspirations in the different value chains of a crop, from the variety selection to genetic improvement constitute a research priority. The present study took into account peanut growers and processors. Majority of them are illiterate. Dissemination of new agricultural technologies, improving peanut production should be done in local languages, as recommended by Daudi et al. (2018). The different responses of growers and processors indicate that they use five (5) criteria for selecting peanut varieties. Those include the yield (seeds and pods), the seed size, the number of seeds per pod, the oil content, and the paste quality (roasted peanut seed milling). Banla et al. (2018) and Loko et al. (2020) also found that peanut growers from Togo and Benin have several criteria for selecting peanut varieties. Our respondents prefer grain yield $(89.28 \%)$ than pod yield per plant $(53.57 \%)$. This could be explained by the fact that some harvested pods may already be damaged by pests or contain small/abnormal grains. Indeed, rats were identified as a major production constraint that can cause about $10 \%$ of grain loss in peanut fields (Syed et al., 2021). Both growers and processors preferred two-seed-per-pod peanut varieties over threeseed-per-pod varieties, since two-seeded pod varieties have the capacity to fill pods, despite several short periods of drought occurring during their production cycle (Issa et al., 2019). This criterion may be interesting and have applications in the adaptation of varieties to climate change.

Although growers focused on yield to better maximize their income, the flow of crop production and trading is driven by processors and consumers' preference (Daudi et al., 2018; Ishikawa et al., 2019). The quantity of oil and dough are important characteristics for patties and doughnuts processors. They have been also mentioned in other studies in Ethiopia and Togo as important criteria of variety selecting (Banla et al., 2018; Abady et al., 2019). The processors surveyed in the present study mentioned that the accessions with better oil quantity and good workable dough are those with small seed sizes.
The assessment of morphological variability within 12 collected peanut accessions indicated that Azii Carder variety reported as semi-erect by Loko et al. (2020), was found to be creeping in the present study. This difference could be attributed to the influence of environmental factors such as light, on the expression traits in peanut (Videgla et al., 2016). Agglomerative hierarchical clustering based on the qualitative traits classified the 12 accessions into 3 morphological units. This result suggests that there are some duplicates within the studied accessions, that can be found out by molecular analysis. This duplication is associated to the different socio-cultural groups studied which give different names to the same cultivar (Dansi et al., 2008). These remarks were also made in other varieties such as fonio, and voandzou (Adoukonou-Sagbadja et al., 2006; Gbaguidi et al., 2018).

Descriptive statistics values of quantitative traits showed high coefficients of variation for time of $50 \%$ flowering and number of seeds per pod, indicating heterogeneity within the studied collection. These agronomic parameters were strongly influenced by the trial environment (Zaman et al., 2011). The average of number of pods per plant (8.12 \pm 0.46$)$ obtained was low, compared to those obtained $(15.9 \pm 5.3 ; 21.40$ \pm 5.02 ) by Jiang et al. (2014) and N'Khoma et al. (2020) in Chine and Zambia, respectively. This is due to the drought period observed during the trial, pest attacks (insects and rats), as well as diseases such as leaf spots on plants during the experiment, because no pesticide was applied. Tanzubil and Yahaya (2017) and Sinare et al. (2021) emphasized that leaf diseases can cause from $20-72 \%$ yield loss in peanuts. Controlling these factors could allow accessions to express their true yield potential. The different groups in the cluster based on the quantitative traits give an idea of performance in the studied accessions. The best parental lines could be obtained from group III (Azii alorga and Kamalo) in order to obtained long-podded and large-seeded progeny, since large-seeded varieties were prized by processors. 


\section{Conclusion}

There is not any formal seed sector in the study area. The peanut seed system is largely dominated by seeds from the local market and from previous harvests of growers. The information collected from growers and processors showed a variability in the selecting criteria preference of varieties. Grain yield was found to be the most important criterion for growers, while processors were more interested to oil content in peanuts. The analysis of agro-morphological traits in the available cultivars revealed a great variability in the cultivars. These different results updated the state of knowledge on peanut diversity in Benin. The improvement of peanut productivity may be relatively associated to the extension programs taking into account the specific needs of stakeholders. In addition, a molecular analysis of the peanut collection would be necessary for a rational diversity.

\section{AUTHORS' CONTRIBUTIONS}

DM designed the study, wrote the proposal and the first draft. PG and AAM performed the data analysis, and literature searches. FA and DATH collected the data, and computed the data. CG and CA revised the manuscript. All authors read and approved the final version of the manuscript.

\section{COMPETING INTERESTS}

Authors have declared that no competing interests exist.

\section{ETHICS APPROVAL AND CONSENT TO PARTICIPATE}

No ethical approval was needed for this study. Prior to data collection, participants gave oral consent to participate in the study.

\section{ACKNOWLEDGMENTS}

The contribution of farmers is highly appreciated. We would also like to extend our gratitude to the anonymous reviewers for their valuable comments and suggestions made to help improve the manuscript.

\section{REFERENCES}

Abady S, Shimelis H, Janila P, Mashilo J. 2019. Groundnut (Arachis hypogaea L.) improvement in sub-Saharan Africa: a review. Acta Agriculturae Scandinavica, Section B-Soil \& Plant Science, 69(6): 528-545.

DOI : https://doi.org/10.1080/09064710.2019.1 601252

Adjou E, Aoumanou M. 2013. Efficacité des extraits de plantes dans la lutte contre les moisissures toxinogènes isolées de l'arachide en post-récolte au Bénin. Journal of Applied Biosciences, 70(1): 5555-5556.

DOI: https://doi.org/10.4314/jab.v70i1.98755

Adoukonou-Sagbadja H, Dansi A, Vodouhè R, Akpagana K. 2006. Indigenous knowledge and traditional conservation of fonio millet (Digitaria exilis, Digitaria iburua) in Togo. Biodiversity and Conservation, 15(8): 2379-2395. DOI: $\quad$ https://doi.org/10.1007/s10531004-2938-3

ASECNA. 2018. Statistiques Agricoles Benin. Agence pour la Sécurité de la Navigation Aérienne en Afrique et Madagascar, Benin. https://benin.opendataforafrica.org/, , (11/09/2020).

Banla EM, Dzidzienyo DK, Beatrice IE, Offei SK, Tongoona P, Desmae H. 2018. Groundnut production constraints and farmers' trait preferences: A prebreeding study in Togo. Journal of Ethnobiology and Ethnomedicine, 14(1): 1-14. DOI: https://doi.org/10.1186/s13002-0180275-y

Bertioli DJ, Jenkins J, levenger J, Dudchenko O, Gao D, Seijo G, et al. 2019. The genome sequence of segmental allotetraploid peanut (Arachis hypogaea). Nat. Genet., 51: 877-884. DOI: https://doi.org/10.1038/s41588019-0405-z

Boukar O, Belko N, Chamarthi S, Togola A, Batieno J, Owusu E, Haruna M, Diallo S, Umar ML, Olufaju O, Fatokun C. 2019. Cowpea (Vigna unguiculata): Genetics, genomics and breeding. Plant 
Breeding, 138(4): $\quad 415-424 . \quad$ DOI: https://doi.org/10.1111/pbr.12589

CoreTeam R. 2018. A language and environment for statistical computing. Vienna: R Foundation for Statistical Computing.

Dagnon YD, Diop S, Bammite D, Glato K, Gbaguidi AA, Dansi A, Tozo K. 2017. Variabilité agromorphologique des cultivars locaux de niébé [Vigna unguiculata (L.) Walp.] au Togo. Afr. Sci. Rev. Int. Sci. Technol., 13(4): 164177.

Dansi A, Adjatin A, Adoukonou-Sagbadja H, Faladé V, Yedomonhan H, Odou D, Dossou B. 2008. Traditional leafy vegetables and their use in the Benin Republic. Genetic Resources and Crop Evolution, 55(8): 1239-1256. DOI: https://doi.org/10.1007/s10722-0089324-z

Daudi H, Shimelis H, Laing M, Okori P, Mponda O. 2018. Groundnut production constraints, farming systems, and farmer-preferred traits in Tanzania. Journal of Crop Improvement, 32(6): 812-828. DOI: https://doi.org/10.1080/15427528.2018.1 531801

Desmae H, Janila P, Okori P, Pandey MK, Motagi BN, Monyo E, Mponda O, Okello D, Sako D, Echeckwu C, OtengFrimpong R, Miningou A, Ojiewo C, Varshney RK . 2019. Genetics, genomics and breeding of groundnut (Arachis hypogaea L.). Plant Breeding, 138(4): 425-444.

DOI:

https://doi.org/10.1111/pbr.12645

Dijkhuizen A, Kennard WC, Havey MJ, Staub JE. 1996. RFLP variation and genetic relationships in cultivated cucumber. Euphytica, 90(1): 79-87. DOI: https://doi.org/10.1007/BF00025163

Dwivedi SL, Scheben A, Edwards D, Spillane C, Ortiz R. 2017. Assessing and exploiting functional diversity in germplasm pools to enhance abiotic stress adaptation and yield in cereals and food legumes. Frontiers in Plant Science, 8:1461. DOI: https://doi.org/10.3389/fpls.2017.01461
FAO (Food and Alimentation Organization of the United Nations). 2020. Statistical Database, Suisse. http://www.fao.org/faostat/en/\#data/QC, (25/01/2021).

Francisco MLDL, Resurreccion AVA. 2008. Functional components in peanuts. Critical Reviews in Food Science and Nutrition, 48(8): 715-746. $\quad$ DOI: https://doi.org/10.1080/10408390701640 718

Gbaguidi AA, Dansi A, Gbemavo DSJC, Orobiyi A, Sanoussi F, Yedomonhan H. 2018. Agromorphological diversity of local Bambara groundnut (Vigna subterranea (L.) Verdc .) collected in Benin. Genetic Resources and Crop Evolution, 65(4): 1159-1171. DOI: https://doi.org/10.1007/s10722-0170603-4

Hamasselbe A, Sadou I, Klassou C. 2011. Genetic variability and correlation among traits explaining resistance to Cercospora leaf spots in groundnut (Arachis hypogaea L.). International Journal of Biological and Chemical Sciences, $\quad \mathbf{5 ( 3 ) :} \quad$ 135-1142. DOI: https://doi.org/10.4314/ijbcs.v5i3.7 2241

IBPGR. 1992. Descriptors for cowpea. international board for plant genetic resources. IBPGR, Benin, $30 \mathrm{p}$.

Ishikawa H, Drabo I, Joseph BB, Muranaka S, Fatokun C, Boukar O. 2019. Characteristics of farmers' selection criteria for cowpea (Vigna unguiculata) varieties differ between north and south regions.of Burkina Faso. Experimental Agriculture, 56: 94-103. DOI: https://doi.org/10.1017/S0014479719000 19X

Issa A, Falalou H, Bakasso Y. 2019. Evaluation des variétés d'arachides (Arachis hypogaea L.) pour la tolérance à la sécheresse. Actes des Premières Journées Scientifiques Nationales, Niamey, 783-796.

Janila P, Nigam SN, Pandey MK, Nagesh P, Varshney RK. 2013. Groundnut improvement: use of genetic and genomic tools. Frontiers in Plant 
Science, 4: 1-16. DOI: https://doi.org/10.3389/fpls.2013.00023

Jiang H, Huang L, Ren X, Chen Y, Zhou X, Xia Y, Yuang J, Lei Y, Yan L, Wan L, Liao B. 2014. Diversity characterization and association analysis of agronomic traits in a Chinese peanut (Arachis hypogaea $\quad$ L.) mini-core collection. Journal of Integrative Plant Biology, 56(2): 159-169. DOI : https://doi.org/10.1111/jipb.12132

Loko YLE, Montcho D, Zandjanakou-Tachin M, Orobiyi A, Toffa J, Hounmakou E, Gavoedo D, Dansi A. 2020. Farmers' management of peanut (Arachis hypogaea L.) diversity, their varietal preference traits and uses in Southern and Central Benin. Journal of Crop Science and Biotechnology, 23(3): 259272.

DOI:

https://doi.org/10.1007/s12892-02000034-9

MAEP (Ministere de l'Agriculture, de l'Elevage et de la Pêche). 2018. Statistiques Agricoles. MAEP, Benin. http://benin.opendataforafrica.org/emcqb $\mathrm{qg} /$ statistiques-agricoles-benin, (05/11/2019).

Nkhoma N, Shimelis H, Laing MD, Shayanowako A, Mathew I. 2020. Assessing the genetic diversity of cowpea [Vigna unguiculata (L.) Walp.] germplasm collections using phenotypic traits and SNP markers. BMC Genetics, 21(1): 1-16. DOI: https://doi.org/10.1186/s12863-02000914-7

Pandey MK, Roorkiwal M, Singh VK, Ramalingam A, Kudapa H, Thudi M, Chitikineni A, Rathore A, Varshney RK. 2016. Emerging genomic tools for legume breeding: current status and future prospects. Front. Plant Sci., 7: 455.

DOI:

https://doi.org/10.3389/fpls.2016.00455
Sanou J, Bationo BA, Barry S, Nabie LD, Bayala J, Zougmore R. 2016. Combining soil fertilization, cropping systems and improved varieties to minimize climate risks on farming productivity in northern region of Burkina faso. Agriculture and Food Security, 5(1): 1-12. DOI: https://doi.org/10.1186/s40066-0160067-3

Sinare B, Miningou A, Nebié B, Eleblu J, Kwadwo O, Traoré A, Zagre B, Desmae H. 2021. Participatory analysis of groundnut (Arachis hypogaea L.) cropping system and production constraints in Burkina Faso. Journal of Ethnobiology and Ethnomedicine, 17(1): $1-15$.

DOI: https://doi.org/10.1186/s13002-02000429-6

Syed F, Arif S, Ahmed I, Khalid N. 2021. Groundnut (Peanut) (Arachis hypogaea). In Oilseeds: Health Attributes and Food Applications, Tanwar B, Goyal A (eds). Springer: Singapore; 93-122. DOI: https://doi.org/10.1007/978-981-154194-0_4

Videgla EG, Floquet A, Mongbo, R, Garba, K, Tossou HS,Toukourou F. 2016. Liens à l'origine et qualité spécifique d'un produit de l'artisanat agroalimentaire du Bénin - le kluiklui d'Agonlin. Cahiers Agricultures, 25(3): 35003.

Zaman MA, Ullah MZ, Moniruzzamn M, Alam KH. 2011. Genetic variability and path analysis of groundnut (Arachis hypogaea L .). The Agriculturists, 9: 2936.

Zinsou VA, Say LG, Fanou A, Sekloka E, Koussinou C, Djenontin AJ, Aweha A, Dramane M, Korogone C, Gagnon F. 2018. Importance of early and late spots of groundnut and selection of varieties for resistance to the diseases in Benin. Tropicultura, 37(4): 1-22. DOI: https://doi.org/10.25518/2295-8010.1416 